\title{
A bi-objective environmental-economic optimisation of hot-rolled steel coils supply chain: A case study in Thailand
}

\author{
Somboonwiwat, T. ${ }^{\mathrm{a},{ }^{*},}$, Khompatraporn, $\mathrm{C}^{\mathrm{a}}$, Miengarrom, T. ${ }^{\mathrm{a}}$, Lerdluechachai, K. ${ }^{\mathrm{a}}$ \\ ${ }^{a}$ Department of Production Engineering, Faculty of Engineering, King Mongkut's University of Technology Thonburi (KMUTT), \\ Bangkok, Thailand
}

\section{A B S T R A C T}

Steel production is an energy intensive industry, emitting a considerable amount of $\mathrm{CO}_{2}$ which contributes to global warming. Many sources of energy may be used in steel production, incurring different costs. This research studies the effects of different decisions in the supply chain network for the production of hot-rolled steel coils (HRSC) in Thailand. The objectives are to minimise the total cost of HRSC production as well as to minimise the total $\mathrm{CO}_{2}$ emissions in order to reduce environmental impact. Towards meeting these two objectives, a mathematical model is proposed to simultaneously determine the choices of energy, raw materials, and transportation modes with regard to production, network, and business constraints. Via examination of the price differences for available raw materials and energy sources several scenarios are investigated to evaluate their impact on both environmental and economic requirements of the supply chain. The analysis shows that the optimal solutions are greatly affected by changes in the prices of slabs and scrap, and the cost of electricity, whereas fuel oil and natural gas prices only affect the choice of fuel for the pre-heating process of the slabs. Strategies to operate under different scenarios are also discussed.
\end{abstract}

\section{ARTICLE INFO}

Keywords:

Hot-rolled steel coils;

Supply chain;

Environmental-economic optimi-

sation;

Energy consumption;

$\mathrm{CO}_{2}$ emission;

Multi-modal transportation

*Corresponding author: tuanjai.som@kmutt.ac.th (Somboonwiwat, T.)

Article history:

Received 4 August 2017

Revised 2 March 2018

Accepted 4 March 2018

\section{References}

[1] Allwood, J.M., Cullen, J.M., Milford, R.J. (2010). Options for achieving a 50\% cut in industrial carbon emissions by 2050, Environmental Science \& Technology, Vol. 44, No. 6, 1888-1894, doi: 10.1021/es902909k.

[2] The Association of Southeast Asian Nations (2016). ASEAN Member States, from http://asean.org/asean/aseanmember-states, accessed March 24, 2017.

[3] International Iron and Steel Institute (IISI) (1997). IISI life cycle inventory study for steel industry products, from https://www.worldsteel.org/, accessed March 25, 2017.

[4] Geilen, D., Moriguchi, Y. (2002). $\mathrm{CO}_{2}$ in the iron and steel industry: An analysis of Japanese emission reduction potentials, Energy Policy, Vol. 30, No. 10, 849-863, doi: 10.1016/S0301-4215(01)00143-4.

[5] Ruth, M., Amato, A. (2002). Vintage structure dynamics and climate change policies: The case of US iron and steel, Energy Policy, Vol. 30, No. 7, 541-552, doi: 10.1016/S0301-4215(01)00129-X.

[6] Zhang, J., Wang, G. (2008). Energy saving technologies and productive efficiency in the Chinese iron and steel sector, Energy, Vol. 33, No. 4, 525-537, doi:10.1016/j.energy.2007.11.002.

[7] Sohaili, K. (2010). The impact of improvement in Iran iron and steel production technology on environment pollution, Procedia Environmental Sciences, Vol. 2, 262-269, doi: 10.1016/i.proenv.2010.10.032.

[8] Tongpool, R., Jirajariyavech, A., Yuvaniyama, C., Mungcharoen, T. (2010). Analysis of steel production in Thailand: Environmental impacts and solutions, Energy, Vol. 35, No. 10, 4192-4200, doi: 10.1016/j.energy.2010. $\underline{07.003}$.

[9] Johansson, M.T., Söderström, M. (2011). Options for the Swedish steel industry - Energy efficiency measures and fuel conversion, Energy, Vol. 36, No. 1, 191-198, doi: 10.1016/i.energy.2010.10.053. 
[10] Lee, Y.H., Kim, S.H. (2002). Production-distribution planning in supply chain considering capacity constraints, Computers \& Industrial Engineering, Vol. 43, No. 1-2, 169-190, doi: 10.1016/S0360-8352(02)00063-3.

[11] Byrne, M.D., Bakir, M.A. (1999). Production planning using a hybrid simulation-analytical approach, International Journal of Production Economics, Vol. 59, No. 1-3, 305-311, doi: 10.1016/S0925-5273(98)00104-2.

[12] Zamarripa, M.A., Aguirre, A.M., Méndez, C.A., Espuña, A. (2012). Improving supply chain planning in a competitive environment, Computers \& Chemical Engineering, Vol. 42, 178-188, doi: 10.1016/j.compchemeng.2012. $\underline{03.009}$.

[13] Dehghanbaghi, N., Sajadieh, M.S. (2017). Joint optimization of production transportation and pricing policies of complementary products in a supply chain, Computers \& Industrial Engineering, Vol. 107, 150-157, doi: 10.1016 /i.cie.2017.03.016.

[14] Gholamian, M.R., Heydari, M. (2017). An inventory model with METRIC approach in location-routing-inventory problem, Advances in Production Engineering \& Management, Vol. 12, No. 2, 115-126, doi: 10.14743/apem 2017. 2.244 .

[15] Koç, U., Toptal, A., Sabuncuoglu, I. (2017). Coordination of inbound and outbound transportation schedules with the production schedule, Computers \& Industrial Engineering, Vol. 103, 178-192, doi: 10.1016/i.cie.2016.11.020.

[16] Jung, K.H., Lee, S.K. (2006). New paradigm of steel mills in the supply chain of automotive sheets, Supply Chain Management: An International Journal, Vol. 11, No. 4, 328-336, doi: 10.1108/13598540610671770.

[17] Organisation Internationale des Constructeurs d'Automobiles (2016). Production statistics, from http:// www.oica.net/category/production-statistics, accessed March 24, 2017.

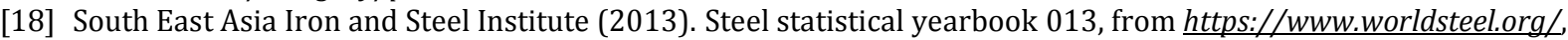
accessed March 24, 2017.

[19] Zadeh, A.S., Sahraeian, R., Homayouni, S.M. (2014). A dynamic multi-commodity inventory and facility location problem in steel supply chain network design, The International Journal of Advanced Manufacturing Technology, Vol. 70, No. 5-8, 1267-1282, doi: 10.1007/s00170-013-5358-2.

[20] The Office of Industrial Economics (2012). Annual report of Thailand economics situation, from $\underline{\text { https://www. }}$ bot.or.th accessed January 30, 2017.

[21] Department of Alternative Energy Development and Efficiency (2011). Annual report of Thailand energy situation 2011, from http://weben.dede.go.th/webmax/ accessed January 30, 2017. 